\title{
Łukasz PONDEL: \\ Chrystologia proegzystencji arcybiskupa \\ Alfonsa Nossola \\ [Archbishop Alfons Nossol's Christology of the Pro-existence]. Opole: \\ Redakcja Wydawnictw Wydziału Teologicznego Uniwersytetu Opolskiego, 2019, 246 pp.
}

The post-Council theology required a specific kind of "refreshment" involving a renewal of the theological discourse, focusing to a much greater extent on the Bible in the research, rediscovering the person of Christ as the centre of all theological reflection and, last but not least, becoming close to the man. The theologian who took it upon himself to renew the said theology, and Christology in particular, in an integral and consistent way, is Alfons Nossol.

For the most part, Archbishop Nossol's works constitute the essential research material of the discussed publication. Cryptic analysis of Nossol's theological works shall be explored in accordance with the rules of logic, hermeneutics, and the comparative method. The explored contents, of key importance to the research being conducted, shall be subject to biblical, theological-Christological, and ecumenical analysis.

Within the proposed "roadmap" of theological rejuvination, Alfons Nossol stresses that theology focused on its dialogical nature, in order for its practice to be closer to the human and life. Shaping the hermeneutics adequate for modern discourse is the next theological accent of this reactivation. Its object would be to reinterpret the dogmas, so that their theo- 
logical message is more transparent. In response to the attempts to replace theology with philosophy of religion, Nossol underscores a more Christocentric orientation of theology. A more profound theological Christo-centrism, in his opinion shall advance a much better understanding of proexistential character of specific dogmatic treaties.

Alfons Nossol, drawing on the insights into the teachings of the Second Vatican Council, proposes a more Bible-based embedment of the research, a Christo-centric orientation of theology and placing the human being at the centre of all theological efforts. In order to do so, it is necessary to build integral anthropology which allows for seeing the person in a complex way, hence also in the triune way, Christo-logical, pneumatological, and eschatological. In order for the renewal to be possible, following from the Vatican II ideology, Nossol recommends making use of such notions as aggiornamento and accommodation. There is no theological regeneration without careful accommodation processes that help theology not to lose from its sight the whole context of particular people's lives, because the Good News of the Gospel is addressed to them, as along with theological language and thinking that is adapted and adjusted to the modern person.

Christological regeneration is central to Archbishop Nossol's theological regeneration. He stresses that the proposed model of Christology requires a more profound interconnecting of the Person of Christ with the Person of Holy Spirit.

Christology in its assumptions, on which Nossol sheds light, also requires eschatological orientation, that is, perceiving the human not only as the addressee of the God's message, but also as the one whose life is directly oriented to God.

The archbishop assumes that theology must be ecumenically open and ecumenically useful. It also applies to his concept of the pro-existence Christology. In particular, it manifests in pro-existential openness to all Christians and people of good will. Openness to another human, not only in one's confessional space, is - according to Nossol - one of the essential tasks of the Christ's Church.

The pro-existence Christology in its theological assumptions and in its theological description constitutes a model of Christian life. For this reason Nossol elaborates on its implications for the social ground. By participating in the Triune God's pro-existential love, Christians allow it to make itself present in their everyday life. Due to its anthropological assumptions, pro-existence Christology makes it possible for the human life to be oriented towards the one who always uncovers the meaning of existence to the creation, which is "being for the other."

A greater openness to Christ renders human life more "Christformed". Owing to the fact that pro-existence constitutes a criterion of 
Christian conduct, a follower champions "the civilisation of love." The pro-existence, according to Nossol, on the one hand constitutes a model life, and on the other, becomes a challenge for each believer to face. Thus, what Nossol puts forward is pro-existential emphasis on the dynamics of God's love in the family, an effective influence of pro-existential Christian ethics on social ethics, as well as on pro-existence in societies by preventing hatred and war. It is the pro-existence Christology based on integral orthodoxy that leads to Christian orthopraxy. The best example of how to translate pro-existential Christology into orthopraxy is the person of St. Joseph. Nossol cites St. Joseph as an example of pro-existence being the origin of all sanctity. Josephology may constitute not only a pro-existential example of sanctity for today's theology, but also a separate treaty practised in cooperation with Mariology and effected in the Christological, pneumatological and ecclesiological context. 